\title{
THE UNITED STATES AND CENTRAL ASIA: STRATEGIC INTERESTS AND ENGAGEMENT IN THE POST-COLD WAR ERA
}

\author{
Roy Anthony Rogers
}

\begin{abstract}
Central Asia, which comprises of five republics namely Kazakhstan, Kyrgyzstan, Tajikistan, Turkmenistan and Uzbekistan, were part of the Soviet Central Asia during the Cold War era and achieved their independence after the disintegration of the Soviet Union in 1991. Since then the United States (US) has started to engage the Central Asian republics bilaterally. Initially, the region did not gain much attention in the US foreign policy as in the early years of post-Cold War era, there were other more pressing issues in East Asia and South Asia which dominated the US intention. Hence, the US did not devise any strategy to ensure coherent actions in the region. The US engaged Central Asia as part of the former Soviet territory and was mainly concerned on issues related to de-nuclearisation and nonproliferation, energy and democratisation. Nevertheless, the region can be considered like a 'double aged sword' to the US because it poses a range of opportunities as well as challenges for the US. Moreover, Central Asia's oil and gas reserves have made the region very attractive to the US business community as an alternative to the Middle East. However, since September 11 the strategic interest of the US in the region has increased and this includes initiating strategic partnership with the Central Asian republics in its war against terror. As such, the US needs to re-evaluate its previous engagements in Central Asia. This study, therefore proposes that the US embraces a more comprehensive strategy by adopting a multilateral approach towards the region.
\end{abstract}

Keywords: Central Asia, United States foreign policy, terrorism, New Great Game, New Silk Road, Russia 


\section{INTRODUCTION}

The objective of this paper is to analyse the relations between the United States (US) and the Central Asian states in the post-Cold War era. It delves into the US interest in Central Asia since the end of the Cold War. This paper has divided its analysis on the relations between the US and Central Asia into two periods: the early years of the post-Cold War (1991-2000) which includes the discussion on the US interest in the region prior to 9/11; and the second part focuses on the post-September 11 era (2001 and beyond). This paper also highlights the impact of the September 11 incident on the region, especially with regard to its relations with the US which led to changes in the latter's foreign policy towards Central Asia. Lastly, this work proposes that the US implements a more comprehensive strategy by adopting a multilateral approach.

Central Asia was formerly known as Inner Asia or Middle Asia. ${ }^{1}$ The idea of Central Asia as a distinct region in the world was first mentioned in the works of Alexander von Humboldt, a German geographer, in $1843 .^{2}$ There are various definitions of the area known as Central Asia but no one definition is universally accepted. One of the most common definitions of the region is that Central Asia consists of the five former Soviet republics of Kazakhstan, Kyrgyzstan, Tajikistan, Turkmenistan and Uzbekistan. However, there are others who include Afghanistan, Mongolia, western parts of the People's Republic of China (PRC) such as Xinjiang and Tibet, northern-Pakistan, northeastern Iran, north-western India as being part of Central Asia. It is a landlocked region bordering Russia to the north and northwest; Iran to the south; and China to the east.

Despite the ambiguity in the definition of the region, it does have some common characteristics such as its history has been closely tied to its nomadic peoples and the Silk Road. Therefore since ancient times the region has been a strategic area and acted as a crossroad for the movement of people, goods, and ideas between Asia and Europe. As the Turks were the early settlers of the region hence the region was also known as Turkestan or the 'land of the Turks'. The Turks in Central Asia speak the Turkic language and the majority of them are Muslims. Islam was first introduced to the region by Arab traders in the seventh century. Persian is also widely spoken in the region aside from Turkic and Arabic. 
The region was ruled by several empires such as the Samanid, Ghaznavid, Seljuks and the Mongols. By the 18th century, the Russians were able to penetrate into Central Asia due to the decline of the Mongol empire. By the end of the 19th century, the entire region was captured by the Russians who 'Russianized' the region through the introduction of the Russian language and culture. ${ }^{3}$ Hence, apart from the Turkic language, Russian is also widely spoken in the region at present. In fact, the Russian language and culture remain dominant till this day. It is noteworthy to mention that most of the present leaders of Central Asia were in fact educated in Russia. After the Bolshevik Revolution in 1917, most of the Russian territories in Central Asia were incorporated into the Soviet Union, and by 1930, the entire region was amalgamated into the Soviet Union by Joseph Stalin. ${ }^{4}$

The unexpected disintegration of the Soviet Union in 1991 led to the independence of these five Central Asian republics. It is worthy to mention here that although the leaders of these Central Asian states were Muslims and former officials of the communist party, administration-wise, they practised secularism and harboured no intentions to establish Islamic republics. ${ }^{5}$ The newly independent republics were Kazakhstan, Uzbekistan, Kyrgyzstan, Turkmenistan and Tajikistan. Their independence caught most of the foreign policy decision-makers in Washington by surprise. While the US policy during the Cold War was focussed on checking the expansion of communism, the disintegration of the Soviet Union in 1991, brought new opportunities and challenges for the US. Recognising the strategic and economic importance of these Central Asian republics, the US was quick to establish diplomatic relations with these states immediately upon their independence. In fact, the US Secretary of State, James Baker, paid a visit to the region in January 1992, barely six months after the independence of these Central Asian republics.

\section{THE US-CENTRAL ASIA RELATIONS IN THE EARLY YEARS OF THE POST-COLD WAR ERA (1991-2000)}

The historical visit of Secretary of State, James Baker, to Central Asia in January 1992 was a watershed in the relations between the US and the region. In fact, it was the first visit of a senior official from the US government to the region immediately after the disintegration of the Soviet Union. Initially, the US relations with the Central Asian 
republics were under the preview of the European Bureau of the State Department. However, in 1993, the State Department established a provisional structure to handle its relations with Russia and the former Soviet territories. ${ }^{6}$ In October 1996, James Collins, a special coordinator at the US Department of State for Russia and the CIS, laid down eight major concerns of the US in Central Asia in the 1990s. These were to:

1. support the independence, sovereignty and security of the Central Asian republics;

2. assist in the formation of a market economy and democratic forms of administration, based on equal opportunities and the observance of human and civil rights;

3. promote the integration of these states into world community of political and financial organisations and also their participation in the Euro-Atlantic dialogue regarding the issues of security and cooperation.

4. contribute to the establishment of peaceful relations among states of Central Asia and with their neighbours, to the creation of new dimension of regional cooperation and to the resolution of local conflicts through international mediation;

5. prevent illegal commerce in weapons of mass destruction, either within or outside the region;

6. cooperate in dealing with other international problems such as terrorism, narcotic and protection of the environment;

7. advance the commercial interests of the US; and

8. promote the expansion and diversification of the global sources of energy. ${ }^{7}$

In a nutshell, the US interest in the region prior to $9 / 11$ can be summarised into five main areas namely denuclearisation; security arrangements for the region; political and economic reforms; energy diplomacy (oil and gas); and balancing the presence of other major powers in Central Asia, namely Russia and China. ${ }^{8}$ 


\section{Denuclearisation and Security Challenges}

The most pressing concern for the US in the post-Cold War era was the presence of large quantities of nuclear arsenals and weapons of mass destruction (WMD) in Central Asia. At the end of the Cold War, Kazakhstan, one of the former Soviet territories, had a large amount of nuclear weapons within its borders. Among these were 1,400 nuclear warheads and the $104 \mathrm{SS}-18$ intercontinental ballistic missiles (ICBM). ${ }^{9}$ Besides that, Kazakhstan also possessed the ability to launch nuclear attacks, which it inherited from the Soviet. This ability included ICBM launchers, nuclear weapons silos and strategic bombers.

The declining economic condition and widespread corruption in post-Soviet Central Asia made the presence of nuclear weapons a pressing concern. Hence, removing and destroying these weapons was the top agenda of the US. In addition, the US was also concerned with the proliferation of such weapons, especially with the geographical proximity of Kazakhstan to other countries such as Iran and Pakistan - both aspiring to obtain nuclear weapons at that time. Moreover, the fear of WMD in Kazakhstan falling into the hands of extremist groups such as the Taliban, Al-Qaeda, Hizb ul-Tahir and Islamic Movement of Uzbekistan (IMU) deepened the concern of the US. ${ }^{10}$

As a result of this growing fear, in December 1993, the US initiated the 'Cooperative Threat Reduction' (CTR) programme in Central Asia, which was aimed at enabling the former USSR territories in the region to withdraw their nuclear arsenals safely. ${ }^{11}$ The agreement was signed between US Vice-President Al Gore and Kazakhstan's President, Nursultan Nazarbayev. This led to cooperation between the US and Kazakhstan in dismantling the 104 SS-18 missiles. ${ }^{12}$ Further, in 1994, the US and Russia initiated a joint effort known as the 'Sapphire Project' to remove large amounts of nuclear weapons (600 kilograms) and uranium from Ulba in Kazakhstan. ${ }^{13}$ In addition, Kazakhstan also signed the Treaty on the Non-proliferation of Nuclear Weapons (NPT) and agreed to withdraw all its nuclear arsenals by the following year. By June 2002, Kazakhstan was able to dismantle all the remaining nuclear silos with the assistance from the US. A similar treaty (CTR) was also signed between the US and Uzbekistan in June 2001 which was aimed at preventing the proliferation of weapons of mass destruction. ${ }^{14}$ 
Apart from the problem of proliferation of nuclear arsenals, there were also concerns on the proliferation of conventional arms in Central Asia. This was because a huge amount of weapons were smuggled into the region through the Afghan border. This not only had the potential to destabilise the region but even created fear as well as anxiety in Washington should these weapons fall into the hands of extremists. The weak administration and economic hardship as well as widespread corruption in the region subsequently contributed to the spread of transnational organised crime and narcotics trafficking. Poverty was a major reason for the rise in narcotic activities in Central Asia which provided quick profits to local peasants and corrupt government officials. It was estimated that the area used to cultivate poppy was roughly around 300,000 acres. ${ }^{15}$ As such, this resulted in Central Asia becoming the largest opium producing area in the world. Besides raw opium, marijuana and hashish were also produced in large quantities. Consequently, there was a growing fear that the narcotic mafias would cooperate with extremist groups to destabilise the region.

\section{The US-Central Asia Security Arrangements}

Security threats from Central Asia (such as narcotics, proliferation of nuclear arsenals and transnational organised crime) during the early 1990 s prompted the United States to take more interest in the region. Therefore, the US initiated several security arrangements within the framework of the North Atlantic Treaty Organisation's (NATO) Partnership for Peace (PfP) programme. ${ }^{16}$ The aim of such cooperation was to enable both the Central Asian republics and the US to counter security threats, which would have destabilised the region and subsequently, jeopardised the US interest. According to President Nazarbayev, "the North Atlantic Treaty has a suitable goal for our rapprochement to assist the democratic development of the states of Central and Eastern Europe and the CIS, and to prevent regional conflicts as far as possible."17

The Central Asian leaders also believed that active military cooperation within the NATO PfP programme would enable them to be closer to the Western security structures and reduce dependency on Russia. However, it is noteworthy to mention that despite the active security partnership between the US, NATO and the Central Asian 
republics, this did not meant Russia withdrew its security engagement in the region.

The US-NATO PfP-Central Asia military cooperation consisted of joint military exercises as well as training and exchange of military personnel. Since its inception in 1994, there have been several USNATO-Central Asia military exercises such as the Cooperative Osprey Exercise in North Carolina (August 1996), Ultra Balance-97 in Almaty, Kazakhstan and Centrasbat-98 in Tashkent, Uzbekistan. In addition, the US together with the NATO forces also assisted in developing the Central Asian Battalion (CENTAZBAT). ${ }^{18}$ The objective of the CENTAZBAT was to coordinate peace-keeping exercises between the US-NATO PfP and Central Asian republics. Apart from joint exercises and training, cooperation between the armed forces from the Central Asian republics and members of the NATO was further enhanced through exchange of military personnel. ${ }^{19}$ In addition, senior officials from both the NATO and Central Asia met on a regular basis. Among the many meetings were the US permanent representative to the NATO, Robert Hunter's visit to Central Asia in April 1996; followed by the NATO Secretary General, Javier Solana's visit to Almaty, Kazakhstan the following year. ${ }^{20}$

With the passing of the US Silk Road Strategy Act in March 1999, bilateral relations between the former and the region were further enhanced as it was aimed at promoting greater cooperation in the areas of security, energy and economy. ${ }^{21}$ It also enabled the US to support economic and political independence in Central Asia by providing more economic and technical assistance. In 2000, the US offered the each Central Asian republic USD 3 million as additional security assistance to counter the narcotics problems and transnational organised criminal activities. ${ }^{22}$

\section{US Energy Diplomacy in the Caspian-Central Asia Region}

The Central Asia-Caspian region has been known for having huge untapped hydrocarbon resources. According to the estimation by the Energy Information Administration of the US Department of Energy (DoE), Kazakhstan has roughly 9 to 40 billion barrels of oil reserves and 65-100 trillion cubic feet of natural gas $^{23}$ - thus making it the country with the largest oil and gas reserves in the region. Both 
Uzbekistan and Turkmenistan have oil reserves of approximately half a billion barrels. In addition, Turkmenistan's gas reserves are estimated at 71 trillion cubic feet while Uzbekistan's gas reserves are estimated at 66 trillion cubic feet. ${ }^{24}$

Similarly, according to the 1997 Caspian Region Energy Development Report published by the US Department of State, the estimated oil reserves in the Caspian basin were approximately 200 billion barrels. ${ }^{25}$ These figures have attracted many US oil companies such Exxon and Amoco Corporation to invest in the Central AsiaCaspian region. ${ }^{26}$ However, one major problem that these land-locked countries face is the difficulty of transporting their oil and gas to international markets. This problem is even more crucial for the US, which competes with nations such as Russia and China that are equally interested in the region's oil and gas sector.

In addition, the US also faces the dilemma of building pipelines. If the US were to build its pipelines to the north, then it faces competition from the Russians who have pipelines via their territory. Therefore, the northern route makes little sense for the US given the fact that Russia too is interested in the oil and gas industry in Central Asia. Another possible route is via Iran and into the Persian Gulf, which is of relatively shorter distance. ${ }^{27}$ However, the said route is considered unviable both the US and Iran do not have formal diplomatic relations. There were also other possible routes like the 'eastern route' running across Kazakhstan via China and to the Pacific and the 'southeast route' running across Afghanistan via Pakistan and into the Indian Ocean. Although they seem to be a solution for the US but neither routes are viable. If the US were to develop the eastern route it will also encounter competition from China who has an interest in oil and gas in Central Asia. In the case of the southeast route, this again was considered not feasible mainly due to the instability in Afghanistan.

As such, the US was left with only one possible route that is the East-West Corridor which would enable the US to transport oil and gas from Central Asia-Caspian basin to the Western markets via Azerbaijan, Georgia and Turkey and into the Mediterranean Sea. The construction of these pipelines started in the late 1990s and was completed in 2005. The East-West Corridor or known as the 'Azerbaijan-Georgia-Turkey Corridor' bypasses Russia and 
Iran. ${ }^{28}$ Moreover countries like Azerbaijan and Georgia welcomed the presence of the US in the region mainly to counter-balance the overwhelming influence of Russia. With the pipelines operational, it enables the US companies to transport the Central Asia-Caspian basin oil and gas to the Western markets.

Apart from oil and gas, Central Asia is also rich in other resources. For example, Uzbekistan has one of the largest gold deposits in the world and is also a major producer of cotton. Similarly, Tajikistan has one of the world's largest aluminium processing plants. In addition, Kyrgyzstan is also a major exporter of cotton and gold. ${ }^{29}$ As a result, many American companies have expressed their intentions to invest in Central Asia. Hence, several trade agreements were signed between the US-based institutions such as the Overseas Private Investment Corporation (OPIC) and the US Exim Bank with the Central Asian republics. ${ }^{30}$

\section{Economic and Political Reforms in Central Asia}

In the 1990s, apart from security, economy and energy issues, the US was also interested in assisting the Central Asian republics in reforming their economic and political structures from one that were formerly centrally-planned and authoritarian into market-based economies coupled with strong democratic governance. As such, Washington firmly believed that it had the profound duty to assist these newlyindependent Central Asian republics. The US foreign policy towards Central Asia in the 1990s was also influenced by the euphoria of the collapse of Communism and triumph of neo-liberal ideas. Some US policy-makers, influenced by neo-liberal ideas, were convinced that the US had a duty to promote capitalism that included free trade and market-driven policies and encourage these states to liberalise their political systems through democratisation.

In order to achieve these goals, the US provided significant efforts in terms of economic and technical assistance. ${ }^{31}$ In fact, in December 1993, the US Agency for International Development (USAID) provided USD 379 million in humanitarian assistance to the Central Asian republics. ${ }^{32}$ In addition, the USAID also offered technical and training programmes on administration, financial and tax policy, privatisation and developing small enterprises. Various humanitarian 
organisations based in the US like the Peace Corps and Mercy Corps also sent volunteers to Central Asia to teach and train the locals. ${ }^{33}$

However, the US did not always receive positive response from the Central Asian leaders especially regarding political reforms. They had feared such reforms would pose a challenge to the survival of their regimes. In addition, they were also concerned that issues pertaining to human rights and democratisation might be used as a tool by the US to interfere with their domestic policies. It is worthy to mention that the US efforts in supporting economic and political reforms in Central Asia can also be viewed from the neo-realist perceptive namely as the US has an ulterior motive in enhancing its relative interest in the region by developing future markets for the US and expanding its political influence aimed at balancing growing Chinese presence. ${ }^{34}$

\section{THE US-CENTRAL ASIA RELATIONS POST 9/11}

The attacks of 11 September 2001 was a turning point in the relations between the US and Central Asia as it led to a more pro-active role for the US in Central Asia. This was clearly stated by the US Secretary of State, Colin Powell, in December 2001 when he reiterated that "the US interest in the Central Asia region stretched beyond the crisis in Afghanistan." 35 Similarly, the US Deputy Secretary, James Wolfowitz, had also confirmed the change in the US' foreign policy towards Central Asia and reaffirmed the US commitment to the region. He was quoted as saying that "by upgrading its military presence in Central Asia, the United States wishes to send a clear message to regional countries that it (the US) will not forget about them."36 Interestingly, during his visit to Afghanistan, US Senator Joseph Libermann too admitted that the US had made a mistake by not giving enough attention to the security development of the region in the 1990s. He noted that "we learned at a very high and painful price, the cost of a lack of involvement in Central Asia on 11 September and we are not going to let it happen again." 37

As such, Central Asia became a strategic ally of the US in its war against the Taliban in Afghanistan. Top US officials such as the US Defence Secretary, Donald Rumsfeld, and the US Secretary of State, Collin Powell, visited Central Asia between October and November 2001, as part of their effort to garner support from the Central Asian 
republics. One of the countries visited by Rumsfeld was Uzbekistan, namely due its geographical proximity to Afghanistan. ${ }^{38}$

The US was able to convince the Uzbek government to allow it to use the Karshi-Khanabad (K2) base for the US Special Operation Forces offensive combat operations in north Afghanistan. In March 2002, Uzbek President, Islam Karimov, visited the US and signed the US-Uzbekistan Declaration on Strategic Partnership and Cooperation Framework which reaffirmed the US commitment to cooperate with Uzbekistan in combating transnational threats and Uzbekistan's efforts to intensify its democratic transformation. ${ }^{39}$

The US was also able to influence Kyrgyzstan to allow it to set up a military base at the Manas-Granci International Airport. By mid-2002, the US had already deployed 3,000 troops in Kyrgyzstan. ${ }^{40}$ Similarly, Tajikistan offered the US forces to use three of its air bases for combat operations and humanitarian missions. ${ }^{41}$ In October 2001, the US, together with other coalition forces, launched the attacks on the Taliban regime in Afghanistan and within two months they were able to ouster the Taliban from power.

The presence of US forces in Central Asia pose serious implications for Russia and China. During the 1990s, as there was a power vacuum in the region, the Central Asian republics began allying themselves with Russia and China. However, the presence of the US has challenged Russia and China as the region's pre-eminent powers and it also provided an opportunity to local leaders to balance Russia's overwhelming influence.

It must be noted that despite the USSR's disintegration, Russia has retained its influence in Central Asia. Russia has an advantage over the region because the Russian language is not only the region's lingua franca, even most of the leaders of Central Asia were in fact educated in Russia. In the fields of economy and energy, the Russians have not shown keen interest in Central Asia. In fact, they have been upgrading the 'North-South Corridor' pipelines, which run exclusively through Russian territory. ${ }^{42}$ The aim is compete with the 'East-West Corridor' as the major pipelines to the Western market. Apart from economy, Russia is also concerned with the rise of Islamic militancy in the region, namely its spill-over into Chechnya. Russia claims that the militant 
groups operating in Central Asia such as the Al-Qaeda and Hizbul-utTahrir are supporting the separatist movement in Chechnya. ${ }^{43}$

Similarly, China is also greatly interested in the region. ${ }^{44}$ Since the 1990s, China has frequently expressed its concern over the security and stability of Central Asia and fears the rise of Islamic militancy in the region. Moreover, the Chinese are convinced that some Uyghur separatists from the Xinjiang Uyghur Autonomous Region (XUAR) are linked with extremists groups in Central Asia. This conviction stems from the participation of some Uyghurs from Xinjiang, in the Afghan War during the $1980 \mathrm{~s}^{45}$ in which they supported the Afghan mujahideens in their struggle against the Soviets. Apparently, these Uyghurs were sent to Pakistan and Saudi Arabia to study Islam in madrassas (Islamic religious schools) and then trained as jihadis to fight the Soviets. ${ }^{46}$ They eventually returned to Xinjiang with the aim of liberating Xinjiang from Chinese rule and establishing an Islamic Uighurstan or East Turkestan. ${ }^{47}$ It must be mentioned that leaders such as Juma Namangani of the Islamic Movement of Uzbekistan (IMU), Hasan Mahsum of the East Turkestan Islamic Movement (ETIM) and Mullah Muhammad Omar are members of the Islamic militant network in Central Asia and Afghanistan who share similar ideas and cooperate with each other to achieve their respective aims. ${ }^{48}$ Therefore, China has worked closely with Central Asian republics bilaterally and multilaterally to fight against religious extremism and terrorism.

The Shanghai Cooperation Organisation (SCO) provides a tool for China to seek multilateral cooperation from other Central Asian republics in combating terrorism, separatism, extremism and transnational crime. China is aware that it has limited military ability to ensure its security on its north-western frontier. Therefore, it has sought regional cooperation in preventing extremist groups in Central Asia from supporting separatist groups in Xinjiang.

Apart from security reasons, China also has economic interests in the region. Since early times, Central Asia has been very important for China's economy as it was part of the Silk Road connecting China with traders from the West such the Byzantium and Ottoman empires. ${ }^{49}$ However, Sino-Soviet rivalry in the 1960 s contributed to a decline in interest from China and relations between China and the Soviet Central Asian republics weakened. Nonetheless, since the disintegration of 
the USSR, China has reaffirmed its interest in Central Asia the latter is not only rich in natural resources, such as oil and natural gas but even serves as markets for Chinese goods. ${ }^{50}$ As such, China aspires to reconstruct the ancient Silk Road in Central Asia by sponsoring the building of modern highways and railroads that connects China with the Central Asian republics. Similarly, China has also forged trade agreements with the Central Asian republics. For example, during the official visit by President Jiang Zemin to Kazakhstan in July 1996, a joint declaration was made to promote strategic partnership between the two countries. ${ }^{51}$ As a result, in June 1997, the Chinese National Oil Company was able to acquire a 60 percent stake in Kazakhstan's Aktiubinsk Oil Company. ${ }^{52}$ Caravans that once travelled the ancient Silk Road have now been replaced by pipelines on the modern Silk Road. ${ }^{53}$

In the post 9/11 era, relations between the US with Russia and China in the region can be viewed as 'bitter-sweet'. ${ }^{4}$ On the one hand, this is because both Russia and China have welcomed efforts undertaken by the US forces to counter terrorism in Central Asia. Both countries also face separatist movements within their own border. In October 2001, both Russia and China even provided support for the US' military campaign in Afghanistan and did not object to the presence of the US forces in Uzbekistan and Kyrgyzstan as they considered it necessary in the ouster of the Taliban regime. ${ }^{55}$

However and on the other hand, the prolonged US presence in Central Asia has created a dilemma for China and Russia. In actual fact, China and Russia view the US as a challenge and threat to their dominant status in the region. China fears that the US has already encircled it, with American troops stationed in South Korea, Japan and Central Asia. ${ }^{56}$ Therefore, as a means to counter-balance the US, China has pursued stronger relations with Russia.

During the SCO heads of state meeting held in Astana, Kazakhstan in July 2005, the organisation officially requested the US to express its intentions regarding its military presence in Central Asia. It also urged the US to clarify when it planned to withdraw its forces. Both Russia and China openly expressed their desire in wanting the US forces to withdraw from the region. Apart from that, the US was not invited as a member or even observer in the SCO. In addition, the SCO 
annually conducts military exercises as a signal to Washington that they are capable of managing the security of the region. In addition, China and Russia also held joint military exercises in the eastern Chinese province of Shandong in August 2005. In July 2007, members of the SCO conducted a military exercise known as 'Peace Mission 2007' in the Urals, Russia. It was the largest military exercise ever organized by the SCO since its establishment in 2001, which involved land and air forces as well as precision weapons. The former Russian Defence Minister, Sergei Ivanov, expressed that the aim of the military exercise was to counter terrorism in Central Asia. ${ }^{57}$ However, he also stressed that the SCO was not a military alliance like NATO. ${ }^{58}$

Apart from Russia and China, the Central Asian republics have also felt uneasy with prolonged US presence in the region. For reasons of regime security, these leaders feared that the US support for political change and reforms might encourage revolutions. Since November 2003, the region has witnessed several political uprisings like the Rose Revolution that resulted in the overthrow of Eduard Shevardnadze of Georgia; the Orange Revolution in Ukraine which caused Viktor Yanukovych to be replaced by Viktor Yushchenko as Prime Minister; and the Tulip Revolution in Kyrgyzstan which resulted in the overthrow of Askar Akayev. ${ }^{59}$

However, the local leaders were unable to accept that the US would support peaceful revolutions and promote democratisation. Therefore, they started to perceive the prolonged US presence as a threat to the survival of their regimes rather than a source of protection. Relations between the US and the Central Asia republics further deteriorated in May 2005 when the US accused the Uzbekistan government for using excessive force to subdue peaceful demonstration by residents of Andijon who demanded for a fair trial of their leader who was charged. As a result, in July 2005, the Uzbek government requested the US to vacate their bases in Karshi-Khanabad, which they had occupied since $2001^{60}$ - which the US vacated in November 2005. Similarly, in February 2009, the Kyrgyz government threatened to close the US air base in Manas when both the governments failed to agree on a higher rent. Nevertheless, in June 2009, after much negotiation, the US was able to convince the Kyrgyz government to allow them to maintain their air base by offering to pay USD 180 
million as rental for the facilities compared to USD 17 million in the previous year. ${ }^{61}$

Upon having engaged Central Asia for almost two decades, the US should now re-evaluate its previous engagements in the region. There are several crucial questions, which the Obama administration should consider. They are as follows:

1. How important is Central Asia to the US?

2. What are the new challenges that the US faces in region?

3. What are the responses from the Central Asian republics toward the presence of the US?

4. Who are the US allies in the region?

5. What are the ways to increase the acceptance and cooperation from the Central Asia republics towards the US?

6. How receptive are the Central Asian republics toward the US initiatives on political reforms and democratisation?

\section{NEW ENGAGEMENT STRATEGY IN CENTRAL ASIA}

Since Barak Obama took over as the President of the United States in January 2009, he has expressed that the US will give more attention on the security of Afghanistan and engage the neighbouring states, especially Central Asia, through dialogue to assist the US. According to Obama, "I want the American people to understand that we have a clear and focused goal: to disrupt, dismantle and defeat al Qaeda in Pakistan and Afghanistan, and to prevent their return to either country in the future. That's the goal that must be achieved. That is a cause that could not be more just." ${ }^{2}$ This indicates that Central Asia remains a pivotal region to provide support for the US efforts in Afghanistan. Therefore, the Obama administration has two options:

1. to continue with the present policies that are counter terrorism and support for political reforms and democratisation of the region;

2. to adopt a new engagement strategy which is more realistic and pragmatic by taking into consideration the geopolitical conditions of the region. 
The present policies have caused the US to be very unpopular among the Central Asian republics as well as neighbouring powers such as China and Russia. If the Obama administration were to maintain the present policies, the US might not be welcome in the region. This is because the Central Asian republics, China and Russia consider the US as an agent of change rather than a security partner. Countries like China, Russia and Uzbekistan have on numerous occasions expressed dissatisfaction over the presence of the US in the region. Therefore, the continuation of present policies might only result in the US losing the support it requires to protect its interests in the region.

As the proposed new engagement strategy requires a more realistic and pragmatic approach, the US needs to adopt a multilateral approach since its resources and military capabilities are limited. It can never counter terrorism in the region on its own without the support and cooperation from the Central Asian republics, China and Russia. Similarly, neither China, Russia nor any of the Central Asian republics want the US operations to fail in Afghanistan. In fact, none of these states want the Taliban return to power. For the secular regimes in Central Asia, the resurgence of the Taliban will certainly pose a threat to their survival. For the Chinese, if the US were to fail in Afghanistan, this would destabilise the region and consequently jeopardise China's economic interest. This might also lead to instability in the province of Xinjiang. For Russia, the resurgence of Taliban would increase the separatist tendencies it presently faces in Chechnya. Moreover, Russia as well as the US could be a balancer against the rapidly growing presence of China in Central Asia.

With this in mind, it must be noted that Afghanistan is focal point for the Central Asian republics, Russia, China and the US to begin their discussions and cooperation. The Obama administration should engage the SCO to cooperate with them in areas related security and counter terrorism. The US should adopt the SCO as its strategic partner by convincing the organisation that a stable Afghanistan could only be achieved with US presence in the region. Similarly, the SCO should not consider itself as an alternative to the US in solving the security problems of the region because it has limited resources and military capabilities. 
The US-Central Asia-China-Russia strategic partnership can adopt the model of ASEAN+3 or the ASEAN Regional Forum (ARF), where China, Japan and South Korea are dialogue partners with the 10 members of ASEAN. Hence, it is not impossible for the SCO to include non-member states like the US, India and Pakistan as its dialogue partners. This strategic partnership could be called $\mathrm{SCO}+3$ (US, Pakistan and India) or the SCO Regional Forum (SRF-including Japan and countries from the Caspian region such as Azerbaijan, Georgia and Turkey).

One of the most important factors to realise the cooperation is related to the mutual threat perception that these countries share namely with regards to the resurgence of the Taliban and their inability to overcome the problem unilaterally. This is especially so in China's case where there has been an increase in violence and separatist activities in Xinjiang. For a start, China and the other SCO members need to initiate an annual dialogue with the US and other relevant states regarding security issues, which include intelligence information sharing and setting-up of a coordinated task force.

Moreover, the Obama administration has softened its criticism of the local leaders with the aim of not antagonising the members of the SCO and jeopardising the US efforts against the Taliban. The change of approach can be observed when recently the US did not issue official statements condemning Kazakhstan for introducing laws limiting the use of the Internet. Similarly, the US did not protest against the violation of human rights in Xinjiang during the ethnic clashes in July 2009 but rather pressed on China to exercise restraint. ${ }^{63}$

The issue of human rights violations in Xinjiang has been relegated to the back burner in favour of more immediate concerns regarding counter terrorism efforts. As a result, several human rights advocacy groups like the Amnesty International and Human Rights Watch have expressed their disappointment with regards to US policy towards the region. According to Veronika Szente Goldston of the Human Rights Watch, "the pragmatic interests and concerns are contributing to a muted US response to human rights abuses in the region, which is unhelpful and disappointing." ${ }^{64}$

Despite international criticism of the US, the authoritarian regimes are viewed as the lesser evils that are temporarily tolerated in 
order to fight the Taliban. The US has begun to learn from its unpleasant experience encountered in Andijon, Uzbekistan, which resulted in the closure of the K2 bases. Martha Brill Olcott of the Carnegie Endowment for International Peace in Washington opines that the US operations in Afghanistan outweigh any other considerations including human rights. ${ }^{65}$

It is worthy to mention that such a strategy does not mean that the US should remain mute to human rights violation and should not stop its efforts to promote political reforms. However, it should be done through dialogue behind closed doors. This is crucial because based on Admiral Dennis Blair's Intelligence Committee's Annual Threat Assessment Report to the Congress in February 2009, the challenges faced by the US in Central Asia, apart from Islamic radicalism, are economic instability, weak institutions and problems related to inequality. ${ }^{66}$

With all these factors in mind, the Obama administration must be aware that it cannot only adopt a military solution to solve the problems in Central Asia. Hence, it is essential that the US focus on issues related to the economic and social development of the region. According to Professor Sean Roberts, a specialist on Central Asia from the George Washington University, "the greatest threat to instability in Central Asia is not Islamic fundamentalism but the region has gotten a lot worse because of the global economic crisis." ${ }^{97}$

\section{CONCLUSION}

The US started engaging the Central Asian republics since the disintegration of the USSR in 1991. Initially, the region did not occupy an important position in the US foreign policy compared to other regions like East Asia and West Asia. The US strategy was focused on four aims: denuclearisation; encouraging political and economic reforms; supporting the region's integration with Western military institution; and obtaining access to Central Asia's energy resources. The September 11, 2001 tragedy and 'Operation Enduring Freedom' were watersheds in the US-Central Asia relations because since then, the region started to receive greater attention from the US policymakers. 
After September 11, the US did not immediately change its policy towards Central Asia. However, its awareness of the strategic importance of the region grew. It began to give more emphasis on counter terrorism efforts and security cooperation with the Central Asian republics, Russia and China. The US also increased its military presence and set-up bases in the region, which led China, and Russia to feel threatened. In turn, both China and Russia initiated strategic cooperation like the SCO and Collective Security Treaty Organisation (CSTO) with the Central Asian republics as a means to counter-balance the US.

The US under the Obama administration must be aware that it can never resolve the security problems in the region by military means alone. Apart from military and security arrangements, these must be complemented with diplomatic and socio-economic efforts as well. Besides fighting the extremist groups, the US should also focus its resources and expertise on overcoming unequal distribution of wealth, corruption and eradication of poverty - these being among the root causes of radicalisation.

Unlike the previous administrations, the Obama administration should also concentrate on constructing a positive identity among the people. As a result, more socio-economic assistance should be provided to train and educate locals and assist them in the management of resources. The aim is to empower the people to improve their people livelihoods. It is worthy to note that the US should never compromise its values by abandoning its efforts in promoting democracy and respect for human rights through economic and political reforms. Nonetheless, the US must also understand the complexity of the region so that a more pragmatic policy can be adopted.

In addition, there are also many other security issues, which require a multilateral approach. Among them are problems like transnational crime, narcotics and the smuggling of conventional weapons which can eventually destabilise the region. Besides that, the situation in Afghanistan is also unstable as the Taliban has made numerous attempts to resurge. To tackle the Taliban problem and other security-related issues, the US, Russia and China mutually need each other. The US, SCO and CSTO should never view each other as rivals but rather partners. The SCO-US-CSTO relations should be based on 
a productive relationship, engaging and cooperating on issues such as counter-terrorism, separatism and extremism. At the same time, the SCO and CSTO should provide a platform where their members can voice their disagreements on issues related to US policies in Central Asia. Therefore, the constructive partnership should be the basis for the SCO-US relations. Despite their differences, they all share similar concerns, namely the security and stability of Central Asia.

\section{NOTES}

1 Robert Legvold (ed.), Thinking, Strategically: The Major Powers, Kazakhstan and the Central Asian Nexus, Cambridge: MIT Press, 2003, p. 40.

2 Roy Anthony Rogers, "The Shanghai Cooperation Organisation China and the New Great Game in Central Asia," Journal of International Studies, Vol. 3, 2007, p. 93.

3 Dimitri Trenin, "Russia and Central Asia: Interest, Policies and Prospect," in Eugene Rumer, Dimitri Tremin and Huasheng Zhao (eds.), Central Asia Views from Washington, Moscow and Beijing, New York: M.E. Sharpe, 2007, pp. 75-76.

4 Geoffrey Wheeler, The Modern History of Soviet Central Asia, London: Weidenfeld and Nicolson, 1964, p. 139.

5 Ahmed Rashid, Jihad: The Rise of Militant Islam in Central Asia, Middlesex: Penguin, 2003, p. 57.

6 Strobe Talbott, The Russia Hand: A Memoir of Presidential Diplomacy, New York: Random House, 2002, p. 39.

7 Rustam Burnashev, "Regional Security in Central Asia: Military Aspects," in Boris Rumer (ed.), Central Asia: A Gathering Storm?, New York: M.E. Sharpe, 2002, p. 116.

8 Stephen J. Blank, Energy, Economics, and Security in Central Asia: Russia and Its Rivals, Carlisle: US Army War College, 2001, pp. 30-31.

9 Mohammad Monir Alam, "US Policy in Central Asia: Problems and Prospects," in V. Nagendra Rao (ed.), Central Asia Present Challenges and Future Prospects, New Delhi: Knowledge World, 2005, pp. 157-158.

10 Mariam Aboud Zahab and Olivier Roy, Islamist Networks: The AfghanPakistan Connection, London: Hurst \& Co., 2002, p. 5.

11 Robert Cullen, "Central Asia and the West," in Michael Mandelbaum (ed.), Central Asia and the World, New York: Council of Foreign Relations, 1994, pp. 140-141. 
12 Elizabeth Wishnick, Growing Security Interest in Central Asia, Carlisle: US Army War College, 2002, pp. 3-4.

13 Ibid.

14 Jim Nichol, Central Asia's New States: Political Developments and Implications for US Interests, Washington, DC: Congressional Research Service, April 2003, p. 12.

15 Nancy Lubin, "Central Asia: Issues and Challenges for United States Policy," in Ali Banuzizi and Myron Weiner (eds.), The New Geopolitics of Central Asia and its Borderlands, Bloomington: Indiana University Press, 1994, pp. 264-265.

16 Alam, "US Policy in Central Asia," p. 159.

17 Ibid.

18 Lutz Kleveman, The New Great Game: Blood and Oil in Central Asia, New York: Grove Press, 2003, p. 168.

19 Alam, "US Policy in Central Asia," p. 160.

20 Ibid.

21 "Silk Road Strategy Act of 1999," $106^{\text {th }}$ Congress, $1^{\text {st }}$ Session, p. 1-5, $<\mathrm{http}$ ://www.eurasianet.org/resources/regional $>$

22 Wishnick, Growing Security Interest in Central Asia, p. 5.

23 See U. S. Energy Information Administration (EIA), <http://www.eia. gov/countries/country-data.cfm?fips $=$ KZ>

24 Ibid.

25 US Department of State, Caspian Region Energy Development Report, April 1997.

26 "The US in Central Asia," Central Asia Journal, No. 52, 2003, pp. 231232. See also, Manabu Shimizu (ed.), The Caspian Basin Oil and its Impact on Eurasian Power Games, Tokyo: Institute of Developing Economies, June 1998, p. 1.

27 Rob Johnson, Oil, Islam and Conflict, London: Reaktion Books, 2007, p. 204.

28 Ibid., p. 209.

29 Lubin, "Central Asia," p. 264.

30 Ibid., p. 270.

31 Gregory Gleason, "State Building in the Face of Insurgent Islam," in Ashley J. Tellis and Michael Wills (eds.), Strategic Asia 2004-05, Seattle: The National Bureau of Asian Research, 2004, p. 203.

32 Lubin, "Central Asia," p. 269.

33 Ibid., p. 270. 
34 Boris Rumer, "The Search for Stability in Central Asia," in Boris Rumer (ed.), Central Asia: A Gathering Storm?, New York: M.E. Sharpe, 2002, p. 60 .

35 Alam, "US Policy in Central Asia," p. 163.

36 Ibid.

37 Ibid.

38 Kleveman, The New Great Game: Blood and Oil in Central Asia, p. 167.

39 Embassy of the United States, Tashkent, Uzbekistan, "United StatesUzbekistan Declaration on the Strategic Partnership and Cooperation Framework," <http://uzbekistan.usembassy.gov/pr031203.html>

40 Eugene Rumer, "The United States and Central Asia: In Search of a Strategy," in Eugene Rumer, Dimitri Tremin and Huasheng Zhao (eds.), Central Asia: Views from Washington, Moscow and Beijing, New York: M.E. Sharpe, 2007, p. 40.

41 Alam, "US Policy in Central Asia," p. 162.

42 Regine A. Spector, "The North-South Transport Corridor," Central AsiaCaucasus Analyst, 3 July 2002, p. 58.

43 Pavel K. Baev, Challenges and Options in the Caucasus and Central Asia, Carlisle: US Army War College, 1997, pp. 6-8.

44 Rogers, "The Shanghai Cooperation Organisation China and the New Great Game in Central Asia," pp. 94-95.

45 Michael Dillon, Xinjiang-China's Muslim Far Northwest, London: Rutledge Curzon, 2004, p. 95.

46 Zahab and Roy, Islamist Networks, p. 22.

47 Dillon, Xinjiang, p. 95.

48 Rashid, Jihad, pp. 42-44. See also, Rohan Gunaratna, Inside Al Qaeda Global Network of Terror, New Delhi: Roli Books, 2002, pp. 168-173.

49 Morris Rossabi, China and Inner Asia, London: Thames and Hodson, 1975, p. 11.

50 Zhao Huasheng, "New Situation in Central Asia and Shanghai Cooperation Organization," China and Asia's Security, China in the Globalized World Series, Vol. 1, Singapore: Marshall Cavendish, 2005, p. 22.

51 Konstantin Syroezhkin, 'Central Asia between the Gravitational Poles of Russia and China," in Rumer (ed.) Central Asia, p. 182.

52 Ibid.

53 Sean L. Yom, "Power Politics in Central Asia: the Future of the Shanghai Cooperation Organization," Harvard Asia Quarterly, Vol. 6, No. 4, 2002, pp. 48-54.

${ }^{54}$ Rumer, "The United States and Central Asia," p. 58. 
55 Martin McCauley, Afghanistan and Central Asia, London: Longman, 2002, pp. 152-153.

56 Ibid.

57 See <http://www.chinadaily.com.cn/china/china_peace2007_page.html>

58 "SCO to stage joint anti-terror military exercise in 2007", Xinhua, 26 April 2006, <http://english.people.com.cn/200604/26/eng20060426_261341. html>

59 Gleason, "State Building in the Face of Insurgent Islam," p. 201.

60 Rumer, "The United States and Central Asia," p.52.

${ }^{61}$ David L. Stern, "Has Obama put human rights on the back burner?" Global Post, 14 August 2009, <http://www.globalpost.com/dispatch/ asia/090807/us-central-asia-policy $>$

${ }^{62}$ Lee, "A New Strategy for Afghanistan and Pakistan."

63 South China Morning Post, 16 July 2009.

64 Stern, "Has Obama put human rights on the back burner?"

65 Ibid.

66 Joshua Kurcera, "Obama Administration Adopting New Views on Possible Security Threats in Central Asia and the Caucasus," EURASIANET. org, 16 February 2009, <http://www.eurasianet.org/departments/insightb/ articles/eav021709f.shtml>

67 Ibid. 